$10^{\text {th }}$ International Conference on Modern Research in

MANAGEMENT, ECONOMICS and ACCOUNTING

20-22 March, 2020

Berlin, GERMANY

\title{
Determinants of Intellectual Capital Disclosure: An Empirical Study in Jordanian service sector
}

\author{
Dr. Munther Al-Nimer \\ Hashemite University - Jordan
}

\begin{abstract}
:
The study aimed to explore extent level of intellectual capital disclosure in the Jordanian service sector and examine the main factors the effect of level of disclosure by focusing on the profitability indicators and companies' size which measured by total asset and total revenues. In order to attain the study objectives content analysis has been utilized by extracting the relevant data for thirty Jordanian service companies from the annual reports through the period (2014-2018) and based on the intellectual capital disclosure index.

The study revealed that the service companies in Jordan tend to disclose information about their intellectual capital and more concerned with their internal capital and human capital and did not seem to be provided with enough, if any benefit from disclosing external capital. In addition, the study indicated that profitability was in-fact a factor that impact the disclosure of intellectual capital and the service companies size has no impact on disclosure of intellectual capital disclosure.

The study recommended the Jordanian service sector to pay more attention to disclose intellectual capital in order to gain more value and reputation and give a fully image regarding there vital source represented by their intellectual capital.
\end{abstract}

Keywords: Intellectual Capital Disclosure; Jordanian service sector; profitability. 